\title{
Hemoglobin E Disease
}

National Cancer Institute

\section{Source}

National Cancer Institute. Hemoglobin E Disease. NCI Thesaurus. Code C35287.

A condition characterized by the presence of a variant of normal hemoglobin

(hemoglobin E), which is caused by mutation(s) in the gene encoding the beta subunit of the hemoglobin molecule. 